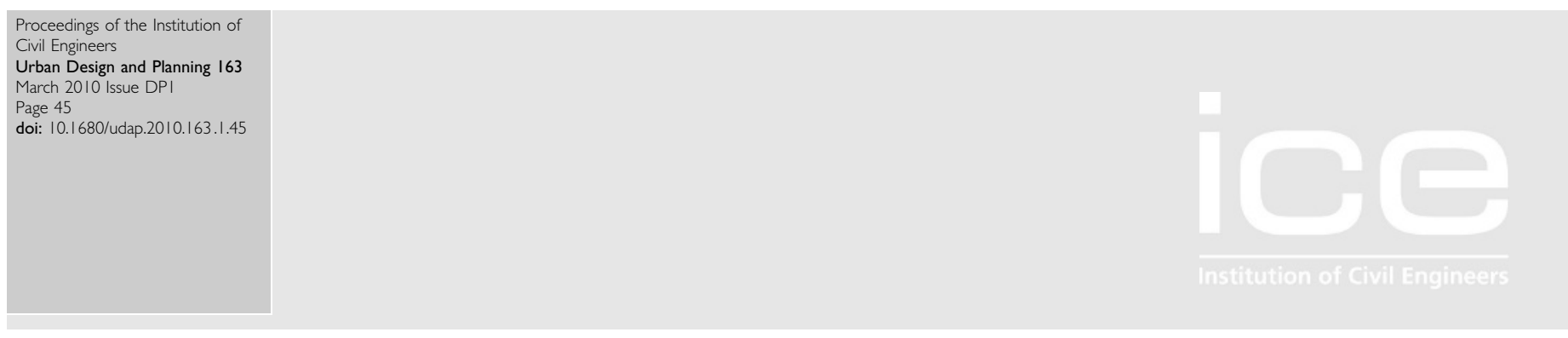

\title{
Elsewhere in ICE Proceedings
}

\section{S. K. Fullalove, Editor}

The following are titles of papers published in other parts of ICE Proceedings during 2009 that readers of Urban Design and Planning may find of interest. ICE Virtual Library is the largest online civil engineering resource in the world. Summaries of all papers are freely available at www.icevirtuallibrary.com/content/journals, and full papers can be downloaded for £15 each. ICE members can download up to 15 papers for a single fee of £29.

Designing and building Belfast's new retail heart M. Gray, S. McCaffrey, F. Blaney, F. McMeel and S. Gallagher Proceedings of the Institution of Civil Engineers, Civil Engineering, 162, No. 4, November, 162-170, doi: $10.1680 /$ cien.2009.162.4.162

The Middle Eastern infrastructure boom: 1945-1995 G. Roberts

Proceedings of the Institution of Civil Engineers, Civil Engineering, 162, Special Issue 2 - The Middle East, November, 4-12, doi: $10.1680 /$ cien.2009.162.6.4

Middle East: building towards a more sustainable approach

B. Cullinane and N. Roberts

Proceedings of the Institution of Civil Engineers, Civil Engineering, 162 , Special Issue 2 - The Middle East, November, 13-17,

doi: 10.1680/cien.2009.162.6.13

Low-carbon energy solutions for an ecological island in China

D. J. Roddy, Y. Yu, D. J. Dufton and P. Thornley

Proceedings of the Institution of Civil Engineers, Energy, 162, No. 2,

May, 85-95,

doi: 10.1680/ener.2009.162.2.85

\section{Social science perspectives on energy transitions}

A. Maassen

Proceedings of the Institution of Civil Engineers, Energy, 162, No. 4, November, 161-167,

doi: $10.1680 /$ ener.2009.162.4.161
Can green infrastructure promote urban sustainability?

C. Mell

Proceedings of the Institution of Civil Engineers, Engineering

Sustainability, 162, No. I, March, 23-34,

doi: 10.1680/ensu.2009.162.1.23

Managing knowledge of urban sustainability assessment C. S. Thomson, M. A. El-Haram and C. Hardcastle Proceedings of the Institution of Civil Engineers, Engineering Sustainability, 162, No. I, March, 35-43, doi: 10.1680/ensu.2009.162.1.35

Integrated policies for environmental resilience and sustainability

J. Hunt

Proceedings of the Institution of Civil Engineers, Engineering

Sustainability, 162, No. 3, September, 155-167,

doi: 10.1680/ensu.2009.162.3.155

The code for sustainable homes

C. Gaze and L. McKeown

Proceedings of the Institution of Civil Engineers, Engineering Sustainability, 162, No. 4, December, 181-184, doi: 10.1680/ensu.2009.162.4.181

Regeneration of large urban areas: assessment methods E. Kazmierczak, S. R. Curwell and J. C. Turner Proceedings of the Institution of Civil Engineers, Municipal Engineer, 162, No. 2, June, 117-124,

doi: $10.1680 /$ muen.2009.162.2.117

\section{Healthy Spaces \& Places project, Australia}

S. Knox

Proceedings of the Institution of Civil Engineers, Municipal Engineer, 162, No. 4, December, 195-197,

doi: 10.1680/muen.2009.162.4.195

Britain's tall building boom: now bust?

R. Skelton, P. Demian and D. Bouchlaghem

Proceedings of the Institution of Civil Engineers, Structures and Buildings,

162, No. 3, June, 161-168,

doi: $10.1680 /$ stbu.2009.162.3.16। 